\title{
Franchising, Ownership, and Experience: A Study of Pizza Restaurant Survival
}

\author{
Arturs Kalnins, Kyle J. Mayer \\ Marshall School of Business, University of Southern California, Los Angeles, California 90089-0808 \\ \{kalnins@usc.edu, kmayer@marshall.usc.edu\}
}

\begin{abstract}
$\mathrm{W}^{\mathrm{s}}$ e hypothesize that retail and service business units will enjoy reduced failure rates if affiliated with experienced multiunit owners and franchisors. Experience of individual owners and franchisees should result in knowledge that is tacit and idiosyncratic and thus primarily of value locally. Because franchisors typically codify knowledge gained from experience, we argue that units should benefit from both local and distant experience of their franchisor. Using Texan pizza restaurant failure data, we found that the units of all multiunit owners, franchised or not, benefited from their owner's local congenital experience, but not from distantly gained experience. Further, the franchisor's local experience reduced failure rates. Contrary to one hypothesis, franchisors' distant experience did not prove beneficial. In addition, a complementary effect was found for owner and franchisor congenital experience. These results highlight the continued importance of local experience, even among the most codified and standardized business organizations.
\end{abstract}

Key words: franchising; chain organizations; knowledge transfer; multiunit ownership; survival

History: Accepted by Linda Argote, organizational performance, strategy, and design; received March $20,2002$.

This paper was with the authors 11 months for 2 revisions.

\section{Introduction}

Retail and service business units affiliated with chains via direct ownership and/or via a contractual relationship with a franchisor have become dominant in the U.S. economy. According to the 1972 U.S. Economic Census, retail units affiliated with a chain in the form of a multiunit owner (i.e., a firm that owns and operates units at multiple geographic locations) generated 44\% (\$202 billion) of total retail sales. By 1997, multiunit firms generated $62 \%$ ( $\$ 1,528$ billion) of total retail sales. Further, in 1995, the units affiliated with chains via a franchising relationship generated more than $\$ 800$ billion in retail and service sales in the United States, more than $12 \%$ of the nation's gross domestic product (International Franchise Association 1996). Practitioner and academic observers have long attributed the dominance of the retail and service sectors by chains to two benefits that units gain from affiliation: the use of a reputable brand name and access to knowledge gained from the chain's experience (see, e.g., Luxenberg 1985, Love 1986, Ingram 1996). Academic research has confirmed that units are less likely to fail as their chains gain experience (Ingram and Baum 1997, Greve 1999). We build on this work by disentangling the unit-level failurereducing benefits of owner and franchisor experience. Further, many units are affiliated with both a franchisor and a multiunit owner. We examine whether a unit's simultaneous access to the two sources of experience and knowledge yields unique benefits unavailable to units affiliated only with a franchisor or a multiunit owner.

The distinction between the experience gained by franchisors and owners is of theoretical importance because the knowledge that results from the two types of chain affiliation may be very different: Franchisors typically codify knowledge and distribute standardized routines to franchisees (Bradach 1997, 1998; Knott 2001, 2003), while individual owners and employees are more likely to serve as repositories for tacit knowledge (Argote and Darr 2001) and for knowledge that is idiosyncratic to a local market (Bradach 1998, p. 45). Nonaka (1994) proposed a complementary relationship between codified and tacit knowledge, providing a theoretical basis for the possibility that units affiliated with both a franchisor and a multiunit owner may be the least likely to fail because of their access to both types of knowledge.

Our second contribution is that we propose and test hypotheses that unit-level failure-reducing benefits of the franchisor's and multiunit owner's experience depend on whether that experience was gained locally or distantly from the unit in question. Existing work has hypothesized and found that units benefit most from experience gained by the chain locally; nonlocal experience has even been found to be harmful (Ingram and Baum 1997, Greve 1999). Our contribution beyond those of the existing work is the insight that the codified and tacit natures of the franchisors' and owners' knowledge, respectively, suggest 
that distance should moderate differently the failurereducing benefits of the two types of knowledge. To build our hypotheses, we draw on previous work suggesting that tacit knowledge is particularly likely to be bounded by distance (Maskell and Malmberg 1999, von Krogh et al. 2000) and that standardization of routines greatly facilitates the transfer of operational knowledge across distance (Adler and Cole 1993, Argote et al. 1990).

We focus on a unit's congenital experience-that is, the experience of the franchisor and the owner at the time of the unit's founding (see, e.g., Huber 1991) rather than ongoing operating experience, because franchising practitioners consistently emphasize the crucial nature of the decisions that need to be made before a unit's startup. For example, Bradach (1998, p. 19) quoted a franchisor development executive as saying, "If you make a mistake at the beginning, it doesn't matter how well you run the unit, because it won't make any money." Perhaps most importantly, the franchisors and owners use their experience to identify appropriate sites for their new units. The site-selection decision is irreversible and has been argued by practitioner guides to be the most crucial determinant of success for retail and service units (Salvaneschi 1996).

The setting in which our hypotheses are tested is the pizza restaurant industry in Texas between 1990 and 1999. Throughout this period, the industry landscape included units affiliated with multiunit owners, franchisors, neither, and both. Substantial unit-level turnover has occurred in this 10-year period, allowing us to meaningfully analyze the likelihood of failure based on the affiliations and experience levels associated with each unit. Pizza restaurants are a particularly appropriate industry for a study of knowledge transfer across geographically separate units because substantial innovation, both codifiable and tacit, has been documented to occur at the unit level, as has the transfer of that innovation (e.g., Darr et al. 1995, Darr and Kurtzberg 2000, Argote and Darr 2001).

The remainder of the paper is organized as follows. We begin with a literature review regarding benefits of owner affiliation and franchisor affiliation. The franchising relationship is also described. In $\S 3$, we develop hypotheses regarding failure-reducing benefits of local and distantly accumulated congenital experience of owners and franchisors. In $\S 4$, we describe the Texas pizzeria data, define our variables, and describe the event history method. In $\$ 5$, we present our core results and describe robustness tests and caveats. Section 5 also contains a supplementary analysis. We analyze separately the failure rates of two groups of franchisor-affiliated units: franchised units and company-owned units of the franchisors. The typical discussion and conclusion sections close the paper.

\section{Background}

\subsection{Affiliation of Units with Multiunit Owners and Franchisors}

Affiliation of multiple operating sites via ownership has been considered superior to market-based relations between sites for the purpose of transferring knowledge and routines from one location to another (Kogut and Zander 1992) and for coordinating and integrating activities across locations (Chandler 1977, p. 235). Consistent with these benefits, Ingram and Baum (1997) found that hotels affiliated with chains, mostly in the form of multiunit owners, had lower failure rates than unaffiliated hotels did. Baum (1999) found that nursing homes affiliated with multiunit owners also enjoyed lower failure rates than did the nursing homes of single-unit owners.

The knowledge transfer literature has found that "similar other" units learn from each other even if separately owned and operated. This result has been demonstrated for hospitals (Byrd 2001), Israeli kibbutzim (Ingram and Simons 2002), and franchised pizza restaurants (Darr and Kurtzberg 2000). Relatedly, affiliation with a chain via franchising has been shown to have performance benefits for individual units (Knott and McKelvey 1999, Litz and Stewart 1998). While knowledge often does not get transferred directly from franchisee to franchisee (Darr et al. 1995), transfer does take place with the franchisor as an intermediary. Argote (1999, p. 91) described a "two-stage" process of knowledge dissemination among franchised units (see also Luxenberg 1985, p. 19). Knowledge that arose from franchisee experience first disseminated directly to the other stores of the same franchisee but only later was transferred by the franchisor-after codification by the franchisor-on a broader scale to other franchisees and to company-owned units.

\subsection{Franchisors and Standardization}

The franchising relationship is a contractual one between a franchisor and a franchisee, who owns and operates one or more units (e.g., restaurants, hotels) of the franchisor's brand. Legally, the franchisor and the franchisee are separate business entities. The franchisee pays an upfront fee along with an ongoing annual sales royalty to the franchisor for the operating rights. The franchisee keeps the residual profit after paying the royalty and expenses associated with operating the unit(s). When a franchisor decides that a new unit should be built in an area, it chooses among the existing franchisees to operate the unit, selects a new franchisee, or owns the unit itself. If a franchisee is chosen, the franchisor works with the franchisee to select the best actual location for the unit (Kalnins and Lafontaine 2004). 
Franchisors typically display an intense commitment to standardizing routines and services across affiliated units (Bradach 1998, pp. 84-111, Knott 2001). McDonald's standardized every aspect of operations, including food preparation, customer service, and cost control (Love 1986, pp. 140-142). Franchisors have an incentive to standardize that multiunit owners do not have, because their franchisees may freeride on the franchisor's brand reputation. Unlike managers at units affiliated with only multiunit owners, franchisees have incentives to provide lowerquality services (Brickley 1999). Franchisors monitor their franchisees to mitigate such free-riding, but without standardization, monitoring becomes very difficult (Kaufmann 1989). Some chains of multiunit owners may, of course, standardize without any franchisor involvement. Hotels affiliated with some multiunit owners standardized their accounting systems, for example (Ingram 1996, pp. 58-62). However, Jakle and Sculle (1999, 110-112) presented anecdotes that multiunit owners unaffiliated with franchisors often do not even attempt to standardize products or routines across units and have difficulty surviving as a result. Thus, overall, we expect franchisors to standardize more than multiunit owners unaffiliated with a franchisor would.

\section{Development of Hypotheses}

\subsection{Congenital Experience for Units Affiliated with Multiunit Owners}

The organizational learning literature has long focused on the relationship of experience and performance (see, e.g., Argote 1999, pp. 1-28, for a review). Consistent with previous work (Ingram and Baum 1997, Greve 1999), we argue that a unit's congenital experience is most valuable when gained by the multiunit owner in an area local to the unit. Local experience leads to an understanding of idiosyncrasies regarding appropriate and inappropriate sites for a possible new unit. For example, after accumulating experience in an area, an owner may have learned how to gather information about future public projects that would make particular sites valuable or worthless. For example, the knowledge that a traffic island was to be constructed on a busy highway, separating the lanes and blocking access to retail units from one direction, was valuable knowledge that made a franchisee avoid that particular stretch of highway (Bradach 1998, p. 19). Further, because much owner and employee knowledge is tacit (Argote and Darr 2000), proximity may aid its transfer (Maskell and Malmberg 1999; von Krogh et al. 2000, pp. 75, 83-84, 92). Managers of nearby units affiliated with the same multiunit owner are more likely to meet face to face repeatedly than those separated by a greater distance, resulting in the transfer of tacit knowledge that may aid site selection as well as unit management.

In contrast to local congenital experience, experience gained by a multiunit owner distantly from a particular unit may be harmful for the unit because the resulting tacit knowledge may be inappropriate (Ingram and Baum 1997, Greve 1999). Multiunit franchisees and owners not affiliated with franchisors typically own clusters of units in one geographical area (Kalnins and Lafontaine 2004, Baum et al. 2000). The tacit knowledge gained by the owner from units in the cluster may well be inappropriate for the occasional unit outside the cluster, where tastes, demographics, and the nature of competition may be different. Further, distance has been shown to inhibit transfer of knowledge between subsidiaries of the same firm (Adams and Jaffe 1996), implying that even if the distantly gained knowledge were appropriate, it may never reach other units located far from the unit where the knowledge was first developed.

We expect similar beneficial effects of locally gained congenital experience of a unit's owner and similar detrimental effects of distant experience for all units, whether or not they are affiliated with franchisors. Therefore, we state only two hypotheses, each of which is tested separately for franchisor-affiliated and unaffiliated units:

Нүротнеsis 1A. The likelihood of a unit's failure will decrease with that unit's congenital experience gained locally by its owner.

Нүротнеsis 1в. The likelihood of a unit's failure will increase with that unit's congenital experience gained distantly by its owner.

\subsection{Congenital Experience for Units Affiliated with Franchisors}

Units affiliated with franchisors should benefit from congenital experience acquired by other owners affiliated with the same franchisor. As mentioned above, Argote (1999) stated that the franchisor transfers knowledge created at franchised units to other franchisees, whose units may be located very far from the innovating unit. The franchisor codifies and standardizes this knowledge before disseminating it to franchisees (Love 1986, p. 140; Bradach 1998, p. 45; Knott 2001, 2003). In the role of the "standardizer," the franchisor typically filters out knowledge and routines that are idiosyncratic to specific markets (Bradach 1998, pp. 118-119). The knowledge and routines filtered out are exactly those that may help multiunit owners locally but hurt them at distant locations. As a result, the knowledge provided by the franchisor will not be perfect for any one location, but should be generic enough to be valuable 
to franchisees at most locations, as long as the franchisor has had some previous experience in areas with similar demographics. Consistent with the idea that franchisors' codified knowledge retains its value across diverse markets, Knott (2001) found that, over time, ex-franchisees abandoned many routines put in place by their franchisor when they left the chain. While these ex-franchisees believed the routines they were abandoning were "not of value in our market" (p. 443), their performance consistently went down as they abandoned them.

Equally importantly, codification and standardization facilitate the knowledge transfer between geographically dispersed units (Adler and Cole 1993, Argote et al. 1990, Zander and Kogut 1995). For these reasons, unlike the case of multiunit owners' experience, we should expect the experience of other owners affiliated with the franchisor to be beneficial to a unit when that experience has been accumulated either locally or distantly.

Нүротнеsis 2A. For units affiliated with franchisors, the likelihood of a unit's failure will decrease with that unit's congenital experience gained locally by its franchisor.

Hypothesis 2в. For units affiliated with franchisors, the likelihood of a unit's failure will decrease with that unit's congenital experience gained distantly by its franchisor.

\subsection{The Complementarity of the Franchisor's and Owner's Congenital Experience}

The interaction of the two forms of chain affiliation on a unit's performance and-more generally-the interaction of codified and tacit knowledge has remained largely unexplored. In one existing study that suggests a complementary role, Bates (1998) found that new units affiliated with franchisors that were also affiliated with a multiunit owner survived longer.

Nonaka (1994) suggested a complementary effect of codified and tacit knowledge, arguing that both are needed within an organization for knowledge creation to take place. We apply this intuition to the case of franchising by arguing that the codified knowledge of the franchisor should complement the tacit knowledge of the franchisees. Practitioner statements illustrate the complementary effects of the franchisor's and franchisees' congenital experience on improving site selection and thus reducing a unit's likelihood of failure. An experienced multiunit franchisee stated that, when searching for sites, the franchisor's managers consistently "remind us of a lot of things we overlook" (Bradach 1998, p. 33). In turn, a franchisor representative stated that, when selecting sites, existing franchisees "know the local conditions, and we rely on this" (Bradach 1998, p. 71).

We also make a related argument that is an application of absorptive capacity (Cohen and Levinthal
1990). This supports the notion that "the ability to evaluate and utilize outside knowledge is largely a function of prior related knowledge" (p. 128). Results suggestive of a localized form of absorptive capacity have been found in the innovation literature. Patents, a form of "outside" knowledge that is clearly codified, have consistently been found to be cited primarily in a geographic area local to their origin (e.g., Jaffe et al. 1993, Almeida and Kogut 1997, Jaffe and Trajtenberg 1999), suggesting that prior and related knowledge that is local and tacit is crucial in enabling scientists to learn from the innovations of their peers.

Our case is similar. The outside knowledge is the codified knowledge provided by the franchisor, while the prior related knowledge is the tacit knowledge that multiunit owners develop locally via their own experience.

HyротHESIs 3. For units affiliated with franchisors, the likelihood of failure will decrease with the combination of the owner's local congenital experience and the local congenital experience of other owners affiliated with the franchisor.

\section{Empirical Research Design}

\subsection{Data}

We analyze data provided by the Texas Comptroller's Office from their Sales and Use Tax Permit File, which includes all pizza restaurants in Texas operating at any time in the 1990s. We are confident that the data are complete, because every restaurant must provide location and ownership information to pay sales tax. The data provide a unit's name, opening date (and failure date, if applicable), street address, owner's name, and headquarters location. No information is available for restaurants that failed before 1990, or for any restaurants outside Texas.

The pizza restaurant industry consists of an interesting combination of units affiliated with franchisors, multiunit owners, both, and neither. Of the 2,474 pizza restaurants in existence in Texas at the end of 1999, there were 1,670 affiliated with multiunit owners and 804 affiliated with single-unit owners; 1,650 were affiliated with franchisors and 824 were unaffiliated with franchisors. Of the 804 units that had single-unit owners, 213 were affiliated with franchisors and 591 were not. By definition, these singleunit firms had no congenital owner experience. Pizza restaurant franchisor affiliation was determined by comparing the business names with the comprehensive sets of chains listed in the Franchise Opportunities Guide trade publications in the 1990s (International Franchise Association 1991-1999).

In 1999, Pizza Hut was the largest franchisor in Texas, with 564 units. Domino's was the second 
largest, with 311 units. The major pizza franchisors operate only one branded pizza chain each. Tricon owned Pizza Hut (though it also owns KFC and Taco Bell), while Domino's and Little Caesar's and the other smaller franchisors were stand-alone corporations. No Pizza Hut owners in our population also owned Taco Bells or KFC units. There were no cases of individual owners owning units affiliated with multiple franchisors, but 16 owners owned both franchisor-affiliated and unaffiliated units.

\subsection{Method}

We tested our hypotheses using event history analysis. Specifically, we used parametric hazard models, which require that a functional form for the transition rates be specified. We estimated regressions using the exponential, Gompertz, and Weibull forms. Because our theory and hypotheses concern only the covariates, and because the results for the covariates did not differ regardless of the model used, we chose to present results using the simple exponential model. The exponential form assumes that the instantaneous transition from origin state (active unit) to destination state (unit failure) at time $t$ does not depend on time $t$, but depends only on the covariates. The general form of the model is $r(t)=\exp \left(\beta^{\prime} X\right)$, where $r$ is the instantaneous transition or "hazard" rate, $X$ is a vector of covariates, and $\beta$ is the vector of coefficients.

Because the values of all our covariates of theoretical interest change over time, we split the life histories of all units into one-year spells and, for each spell, set all covariates to their values at the beginning of that year (see, e.g., Ingram and Baum 1997, Baum and Ingram 1998). The parameters were then estimated by the method of maximum likelihood.

Many pizza restaurants in our sample were founded before 1990. Fortunately, the Texas data set contains founding dates, even if those are before 1990. Therefore, the event history model will only analyze a unit founded in 1980 with others that have survived until the 10th year. The unit will never be mistaken for a new entrant, and problems of left censoring are avoided. See Stata Corp (2001, pp. 441-446) for an extensive discussion on this issue.

\subsection{Variable Definitions}

The dependent variable is the transition rate between active units and their failure. To determine this rate, two statistics are required: the length of time a pizza restaurant has stayed in business and whether the unit is still in business as of December 31, 1999 (i.e., whether it is right censored). The length of time is calculated by subtracting the founding date (or acquisition date by the current owner) from the exit date (if closed) or from December 31, 1999, if the unit is still open for business at that time. Units were considered failures only if they had closed down. Franchisoraffiliated units that became unaffiliated or vice versa were not considered failures.

We measured congenital experience in a manner identical to the existing literature on failure rates within chains (e.g., Ingram and Baum 1997, Baum and Ingram 1998). Like those papers, we calculate

$$
\text { CongExp } \operatorname{Ti}_{T_{i j}}=\sum_{t=T_{j} \text { found }}^{T_{i} \text { found }} \frac{N_{t j}}{\text { Discount }_{T-t}} .
$$

The congenital experience at time $T$ (the period associated with each spell) for unit $i$ affiliated with chain $j$ (the franchisor or multiunit owner) is a summation across all time periods between $T_{j}$ found, which is the founding date (or acquisition date) by $j$ for the very first unit affiliated with $j$, and $T_{i}$ found, which is the founding date (or acquisition date) by $j$ for unit $i$. $N_{t j}$, the count of units affiliated with $j$ at time $t$, is divided by a discount factor to capture the decay in the value of experience over time. The resulting value is summed across all time periods $t$.

The experience is discounted based on the length of time between its occurrence and the current spell; congenital experience should matter less after a unit operates for 10 years than it does at founding. In line with prior research, we estimated regressions using the following values of Discount: $\sqrt{T-t}, T-t$, $(T-t)^{2}$, and 1 (no discount). The factor of $(T-t)^{2}$ indicates the fastest depreciation of the value of experience. The square root discount factor is used in the regressions below because it represents a gradual but nonetheless substantial decay in the organization's knowledge. Estimations using other discount factors are discussed as robustness tests.

For each unit affiliated with a franchisor, separate levels of congenital experience are calculated for the owner of that unit and for its franchisor. The Same Franchisor, Other Owners' Congenital Experience variables include experience gained at the units of other franchisees affiliated with the same franchisor and at company-owned units of that franchisor. For a unit company owned by a franchisor, the Same Franchisor, Other Owners' Congenital Experience variables include experience gained only at the units of franchisees affiliated with the same franchisor. In this case, the experience gained at other company-owned units of the franchisor is included in the Same Owner's Congenital Experience variables.

To distinguish local from distant experience, the congenital experience was considered to be local only if it occurred within the closest 25 units. In other words, we only added an owner's or franchisor's existing units to their respective $N_{t j}$ count if they were within the closest 25 units from unit $i$. Similarly, units were only added to the $N_{t j}$ for distant experience if 
they were outside the closest 25 units (but within Texas). Other ordinal ranges of distance (e.g., the closest 50 or 100 units) as well as the use of administrative boundaries (e.g., counties, zips) were considered as the basis for the operationalization of "local"; these are discussed in the robustness tests section.

In addition to these variables of theoretical interest, we include control variables for the sizes (number of affiliated units) of the chains of franchisors and multiunit owners. These control variables are crucial because size and congenital experience are typically correlated between 0.4 and 0.6. To measure the size of a multiunit owner's chain, we counted the number of units that were open during each spell. These are also split into local and distant groups based on whether they are among the closest 25 units from the unit under observation.

Several other control variables are included. Binary variables are included to identify units that are company owned by franchisors and to identify units that are acquired. Zip code-level counts of local competitors are included to capture the potential effects of competition and/or agglomeration benefits on failure. The count is broken down into units affiliated with other franchisors and unaffiliated units. As a general measure of market size, we include zip code residential population. Per capita income of each zip code (from the 1990 census) is included to control for lucrative markets. The net addition (entries minus exits) of total retail units in the two years previous to the year of each spell is included to control for economic growth.

We also include dummy variables to allow the hazard rates to vary with unit age within the exponential framework. Separate intercepts are included for the first year of a unit's existence, the second year, the third through fifth years, and the sixth through tenth years. Separate intercepts are also included for each calendar year to control for economic shocks. Finally, intercepts are included for each of the 18 franchisors active in Texas. As the franchisors vary in size and level of experience, we do not wish to confound heterogeneity in franchisor quality with the actual effect of the experience; franchisors that have higher-quality brands should eventually be larger and have more experience as a result.

Descriptive statistics for each of the two subpopulations are presented in Table 1 . The subpopulations are based on whether the restaurant is affiliated with a franchisor (used to test Hypotheses 1a, $1 b, 2 a, 2 b$, and 3) or is unaffiliated with a franchisor (Hypotheses $1 \mathrm{a}$ and $1 \mathrm{~b}$ only). There were 2,369 units total at some point affiliated with franchisors and 1,788 at some point unaffiliated. While the vast majority was either always affiliated with a franchisor or always unaffiliated, 107 were at some point affiliated and at some point unaffiliated. Spells from these 107 units appear in the appropriate subsample based on the unit's affiliation status in that spell.

\section{Results}

\subsection{Core Results}

Table 2 displays results from nine separate exponential hazard models that analyze the effects of congenital experience on failure. Models 1-6 analyze franchisor-affiliated units. The first three models test Hypotheses $1 \mathrm{a}, 1 \mathrm{~b}, 2 \mathrm{a}$, and $2 \mathrm{~b}$. The next three include interaction terms to test Hypothesis 3. To minimize the correlation between the primary and interaction terms, we mean-centered the experience and unit count variables when calculating the interaction terms (Aiken and West 1991). Models 7-9 test Hypotheses 1a and $1 \mathrm{~b}$ for units not affiliated with franchisors.

Three models are included for each test because of the moderately high correlations (0.3 to 0.6) between local congenital experience and local number of affiliated units and between local congenital experience and distant congenital experience. The correlations are sufficiently high that the significance of effects may arise only when both of the correlated variables are included. Therefore, we include regressions with the local congenital experience variables together with the distant experience variables and the unit count variables (Models 1 and 7), with distant experience but without the unit counts (Models 2 and 8), and alone (Models 3 and 9). We only claim that a hypothesis is fully supported if significance remains across all three models for each owner type (e.g., Models 1, 2, and 3). If significance remains with and without the correlated variables, we can be sure that high correlations are not causing spurious significance.

Before discussing the results regarding each hypothesis, we note the significantly lower failure rates of units affiliated with franchisors. Only 710 units among the 2,369 units affiliated with franchisors failed $(29.9 \%)$, while 968 of the 1,788 unaffiliated units failed (53.8\%).

The significant and negative coefficients of the Same Owner's Local Congenital Experience variable in Models 1-3 indicate that Hypothesis 1a is supported for franchisor-affiliated units. The significance in all three models assures us of robust support for the notion that the likelihood of failure decreases with the local congenital experience of the owner. Only in Model 1 is the positive coefficient of the Same Owner's Distant Congenital Experience variable significant, and then only marginally so. To be conservative, we conclude that Hypothesis $1 \mathrm{~b}$ is not 

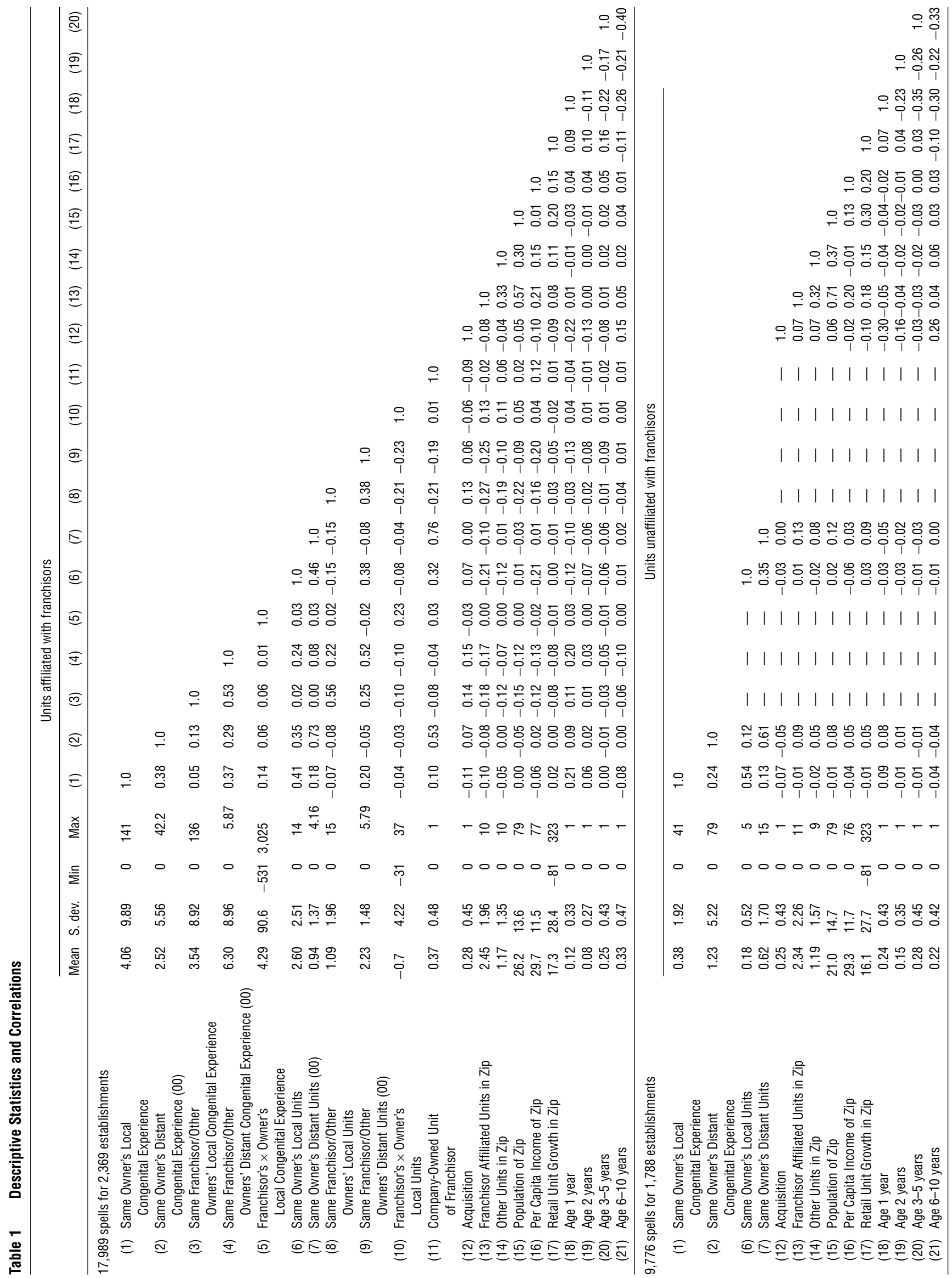
Exponential Hazard Models: Dependent Variable Is Unit-Level Failure

\begin{tabular}{|c|c|c|c|c|c|c|c|c|c|}
\hline & \multicolumn{6}{|c|}{ Affiliated with franchisor 710 failures/2,369 total establishments } & \multirow{2}{*}{\multicolumn{3}{|c|}{$\begin{array}{c}\text { Unaffiliated with franchisor } \\
962 \text { failures/1,788 total establishments }\end{array}$}} \\
\hline & \multicolumn{3}{|c|}{ Without interaction term } & \multicolumn{3}{|c|}{ With interaction term } & & & \\
\hline & (1) & (2) & (3) & (4) & (5) & (6) & (7) & (8) & (9) \\
\hline $\begin{array}{l}\text { Same Owner's Local } \\
\text { Congenital Experience }\end{array}$ & $\begin{array}{c}-0.045^{* *} \\
(0.013)\end{array}$ & $\begin{array}{c}-0.059 * * \\
(0.013)\end{array}$ & $\begin{array}{c}-0.052^{* *} \\
(0.012)\end{array}$ & $\begin{array}{c}-0.055^{* *} \\
(0.015)\end{array}$ & $\begin{array}{c}-0.074^{* *} \\
(0.016)\end{array}$ & $\begin{array}{c}-0.066^{* *} \\
(0.015)\end{array}$ & $\begin{array}{c}-0.092^{* *} \\
(0.032)\end{array}$ & $\begin{array}{r}-0.047^{+} \\
(0.027)\end{array}$ & $\begin{array}{r}-0.053^{*} \\
(0.027)\end{array}$ \\
\hline $\begin{array}{l}\text { Same Owner's Distant } \\
\text { Congenital Experience }\end{array}$ & $\begin{array}{l}0.020 \\
(0.016)\end{array}$ & $\begin{array}{c}0.023^{+} \\
(0.014)\end{array}$ & & $\begin{array}{c}0.021 \\
(0.016)\end{array}$ & $\begin{array}{c}0.026^{+} \\
(0.014)\end{array}$ & & $\begin{array}{l}0.007 \\
(0.011)\end{array}$ & $\begin{array}{c}-1.079 \\
(0.869)\end{array}$ & \\
\hline $\begin{array}{l}\text { Same Franchisor/Other Owners' } \\
\text { Local Congenital Experience }\end{array}$ & $\begin{array}{c}-0.050^{* *} \\
(0.010)\end{array}$ & $\begin{array}{r}-0.018^{*} \\
(0.009)\end{array}$ & $\begin{array}{r}-0.016^{*} \\
(0.008)\end{array}$ & $\begin{array}{c}-0.067^{* *} \\
(0.015)\end{array}$ & $\begin{array}{c}-0.044^{* *} \\
(0.015)\end{array}$ & $\begin{array}{c}-0.040^{* *} \\
(0.014)\end{array}$ & & & \\
\hline $\begin{array}{l}\text { Same Franchisor/Other Owners' } \\
\text { Distant Congenital Experience }\end{array}$ & $\begin{array}{c}0.019^{+} \\
(0.010)\end{array}$ & $\begin{array}{c}0.002 \\
(0.009)\end{array}$ & & $\begin{array}{c}0.018^{+} \\
(0.010)\end{array}$ & $\begin{array}{c}0.002 \\
(0.009)\end{array}$ & & & & \\
\hline $\begin{array}{l}\text { Franchisor's } \times \text { Owner's Local } \\
\text { Congenital Experience }\end{array}$ & & & & $\begin{array}{r}-0.006^{*} \\
(0.003)\end{array}$ & $\begin{array}{r}-0.009^{*} \\
(0.004)\end{array}$ & $\begin{array}{r}-0.008^{*} \\
(0.004)\end{array}$ & & & \\
\hline Same Owner's Local Units & $\begin{array}{r}-0.050^{+} \\
(0.031)\end{array}$ & & & $\begin{array}{r}-0.050^{+} \\
(0.031)\end{array}$ & & & $\begin{array}{l}0.239 * * \\
(0.075)\end{array}$ & & \\
\hline Same Owner's Distant Units & $\begin{array}{c}0.158 \\
(0.187)\end{array}$ & & & $\begin{array}{c}0.125 \\
(0.187)\end{array}$ & & & $\begin{array}{r}-0.008^{*} \\
(0.004)\end{array}$ & & \\
\hline $\begin{array}{l}\text { Same Franchisor/Other } \\
\text { Owners' Local Units }\end{array}$ & $\begin{array}{l}0.223^{* *} \\
(0.027)\end{array}$ & & & $\begin{array}{l}0.200^{* *} \\
(0.032)\end{array}$ & & & & & \\
\hline $\begin{array}{l}\text { Same Franchisor/Other } \\
\text { Owners' Distant Units }\end{array}$ & $\begin{array}{c}-0.024 \\
(0.178)\end{array}$ & & & $\begin{array}{c}-0.050 \\
(0.179)\end{array}$ & & & & & \\
\hline $\begin{array}{l}\text { Franchisor's } \times \text { Owner's Local } \\
\text { Units }\end{array}$ & & & & $\begin{array}{c}-0.019 \\
(0.013)\end{array}$ & & & & & \\
\hline Company-Owned Unit & $\begin{array}{l}0.658^{* *} \\
(0.134)\end{array}$ & $\begin{array}{l}0.625^{* *} \\
(0.107)\end{array}$ & $\begin{array}{l}0.679^{* *} \\
(0.098)\end{array}$ & $\begin{array}{l}0.665^{* *} \\
(0.134)\end{array}$ & $\begin{array}{l}0.625^{* *} \\
(0.107)\end{array}$ & $\begin{array}{l}0.688^{* *} \\
(0.098)\end{array}$ & & & \\
\hline Acquisition & $\begin{array}{c}-0.117 \\
(0.096)\end{array}$ & $\begin{array}{r}-0.098 \\
(0.096)\end{array}$ & $\begin{array}{c}-0.061 \\
(0.091)\end{array}$ & $\begin{array}{c}-0.124 \\
(0.096)\end{array}$ & $\begin{array}{c}-0.103 \\
(0.096)\end{array}$ & $\begin{array}{c}-0.061 \\
(0.091)\end{array}$ & $\begin{array}{r}-0.037 \\
(0.085)\end{array}$ & $\begin{array}{r}-0.040 \\
(0.085)\end{array}$ & $\begin{array}{c}-0.041 \\
(0.085)\end{array}$ \\
\hline $\begin{array}{l}\text { Other Franchisors' Affiliated } \\
\text { Units in Zip }\end{array}$ & $\begin{array}{l}0.070^{* * *} \\
(0.024)\end{array}$ & $\begin{array}{r}0.058^{*} \\
(0.024)\end{array}$ & $\begin{array}{r}0.059^{*} \\
(0.024)\end{array}$ & $\begin{array}{l}0.071^{* *} \\
(0.024)\end{array}$ & $\begin{array}{r}0.058^{*} \\
(0.024)\end{array}$ & $\begin{array}{l}0.059^{*} \\
(0.024)\end{array}$ & $\begin{array}{c}-0.025 \\
(0.022)\end{array}$ & $\begin{array}{l}-0.024 \\
(0.021)(0.02\end{array}$ & -0.026 \\
\hline Other Units in Zip & $\begin{array}{c}0.031 \\
(0.030)\end{array}$ & $\begin{array}{l}0.016 \\
(0.030)\end{array}$ & $\begin{array}{l}0.017 \\
(0.030)\end{array}$ & $\begin{array}{c}0.034 \\
(0.030)\end{array}$ & $\begin{array}{l}0.018 \\
(0.030)\end{array}$ & $\begin{array}{l}0.019 \\
(0.030)\end{array}$ & $\begin{array}{c}0.009 \\
(0.023)\end{array}$ & $\begin{array}{l}0.005 \\
(0.023)\end{array}$ & $\begin{array}{c}0.004 \\
(0.023)\end{array}$ \\
\hline Population of Zip & $\begin{array}{r}-0.008^{*} \\
(0.004)\end{array}$ & $\begin{array}{r}-0.009^{*} \\
(0.004)\end{array}$ & $\begin{array}{r}-0.009^{*} \\
(0.004)\end{array}$ & $\begin{array}{r}-0.008^{*} \\
(0.004)\end{array}$ & $\begin{array}{r}-0.009^{*} \\
(0.004)\end{array}$ & $\begin{array}{r}-0.009^{*} \\
(0.004)\end{array}$ & $\begin{array}{c}0.000 \\
(0.003)\end{array}$ & $\begin{array}{c}0.000 \\
(0.003)\end{array}$ & $\begin{array}{c}0.000 \\
(0.003)\end{array}$ \\
\hline Per Capita Income of Zip & $\begin{array}{c}-0.003 \\
(0.004)\end{array}$ & $\begin{array}{c}-0.004 \\
(0.004)\end{array}$ & $\begin{array}{c}-0.004 \\
(0.004)\end{array}$ & $\begin{array}{c}-0.004 \\
(0.004)\end{array}$ & $\begin{array}{c}-0.004 \\
(0.004)\end{array}$ & $\begin{array}{c}-0.004 \\
(0.004)\end{array}$ & $\begin{array}{c}0.000 \\
(0.003)\end{array}$ & $\begin{array}{c}0.000 \\
(0.003)\end{array}$ & $\begin{array}{c}-0.001 \\
(0.003)\end{array}$ \\
\hline Retail Unit Growth in Zip & $\begin{array}{c}-0.003 \\
(0.002)\end{array}$ & $\begin{array}{c}-0.003 \\
(0.002)\end{array}$ & $\begin{array}{c}-0.003 \\
(0.002)\end{array}$ & $\begin{array}{c}-0.003 \\
(0.002)\end{array}$ & $\begin{array}{c}-0.003 \\
(0.002)\end{array}$ & $\begin{array}{c}-0.003 \\
(0.002)\end{array}$ & $\begin{array}{c}0.001 \\
(0.002)\end{array}$ & $\begin{array}{c}0.000 \\
(0.002)\end{array}$ & $\begin{array}{c}0.000 \\
(0.002)\end{array}$ \\
\hline Age 1 year & $\begin{array}{r}-1.75^{* *} \\
(0.521)\end{array}$ & $\begin{array}{r}-1.75^{* *} \\
(0.519)\end{array}$ & $\begin{array}{r}-1.68^{* *} \\
(0.515)\end{array}$ & $\begin{array}{r}-1.77^{* *} \\
(0.521)\end{array}$ & $\begin{array}{r}-1.78^{* *} \\
(0.519)\end{array}$ & $\begin{array}{r}-1.70^{* *} \\
(0.515)\end{array}$ & $\begin{array}{r}-0.389^{+} \\
(0.236)\end{array}$ & $\begin{array}{r}-0.387^{+} \\
(0.233)\end{array}$ & $\begin{array}{r}-0.400^{+} \\
(0.233)\end{array}$ \\
\hline Age 2 years & $\begin{array}{c}0.231 \\
(0.179)\end{array}$ & $\begin{array}{c}0.241 \\
(0.176)\end{array}$ & $\begin{array}{c}0.304^{+} \\
(0.169)\end{array}$ & $\begin{array}{c}0.216 \\
(0.179)\end{array}$ & $\begin{array}{c}0.221 \\
(0.177)\end{array}$ & $\begin{array}{c}0.294^{+} \\
(0.170)\end{array}$ & $\begin{array}{l}1.49^{* *} \\
(0.147)\end{array}$ & $\begin{array}{l}1.49 * * \\
(0.144)\end{array}$ & $\begin{array}{l}1.48^{* *} \\
(0.144)\end{array}$ \\
\hline Age $3-5$ years & $\begin{array}{c}0.062 \\
(0.131)\end{array}$ & $\begin{array}{c}0.066 \\
(0.130)\end{array}$ & $\begin{array}{c}0.114 \\
(0.126)\end{array}$ & $\begin{array}{c}0.052 \\
(0.131)\end{array}$ & $\begin{array}{c}0.056 \\
(0.130)\end{array}$ & $\begin{array}{c}0.111 \\
(0.126)\end{array}$ & $\begin{array}{l}1.04^{* *} \\
(0.140)\end{array}$ & $\begin{array}{l}1.04^{* *} \\
(0.137)\end{array}$ & $\begin{array}{l}1.04^{* *} \\
(0.137)\end{array}$ \\
\hline Age $6-10$ years & $\begin{array}{c}-0.027 \\
(0.107)\end{array}$ & $\begin{array}{c}-0.056 \\
(0.105)\end{array}$ & $\begin{array}{c}-0.023 \\
(0.104)\end{array}$ & $\begin{array}{c}-0.032 \\
(0.107)\end{array}$ & $\begin{array}{c}-0.058 \\
(0.105)\end{array}$ & $\begin{array}{c}-0.020 \\
(0.104)\end{array}$ & $\begin{array}{c}0.512^{* *} \\
(0.144)\end{array}$ & $\begin{array}{c}0.515^{* *} \\
(0.142)\end{array}$ & $\begin{array}{c}0.512^{* *} \\
(0.142)\end{array}$ \\
\hline Chi squared & 873.8 & 797.9 & 795.0 & 881.1 & 805.7 & 801.9 & 517.8 & 506.0 & 504.3 \\
\hline
\end{tabular}

Notes. Positive coefficients indicate higher probability of failure.

Two-tailed tests: ${ }^{+} p<0.10 ;{ }^{*} p<0.05 ;{ }^{* *} p<0.01$.

All regressions include separate intercepts for each franchisor and for each year.

supported, despite some marginal evidence that failure does increase with the distant congenital experience of the owner.

Models 7-9 in Table 2 examine units unaffiliated with any franchisor. Hypothesis 1a is robustly supported because of the significant and negative coefficients of the Same Owner's Local Congenital Experience variable in all three models. The Same Owner's Distant Congenital Experience variable is never significant, so Hypothesis $1 \mathrm{~b}$ is not supported.
The significant and negative coefficients of the Same Franchisor/Other Owners' Local Congenital Experience. variable in Models 1-3 indicate that Hypothesis 2a is strongly supported. For franchisoraffiliated units, the likelihood of failure decreases with the local congenital experience of other owners affiliated with the franchisor. The significance in all three models assures us of robust support for Hypothesis 2a, because the variable is correlated 0.53 with the Same Franchisor/Other Owners' 
Distant Congenital Experience variable and 0.56 with Same Franchisor/Other Owners' Distant Units. Only in Model 5 is the positive coefficient of the Same Franchisor/Other Owners' Distant Congenital Experience variable significant, and then only marginally so. To be conservative, we conclude that Hypothesis $2 b$ is not supported, despite some marginal evidence that failure does increase with the distant congenital experience of the franchisor.

Models 4-6 test the interaction term associated with Hypothesis 3. The Franchisor's $\times$ Owner's Local Congenital Experience interaction term is significant and negative in all three models, robustly supporting Hypothesis 3. Experience of a unit's owner and experience of its franchisor act as complements in reducing that unit's probability of failure.

Turning to the results regarding control variables, the Same Franchisor/Other Owners' Local Units variable is positive and significant. We note that this variable is robustly significant for regressions (not shown) that do not include any of the congenital experience variables or the distant unit count variables (these are both highly correlated with the local unit counts, and thus could be influencing its significance in Models 1 and 4). While beyond the scope of this paper, this result suggests "encroachment," the habit of franchisors to saturate markets to the point where units of the same brand become each other's primary competition (see, e.g., Blair and Lafontaine 2002, Kalnins 2004, for more on this). The one other control variable that consistently shows significance is Other Franchisors' Affiliated Units in Zip. Franchised units are more likely to fail when higher counts of units affiliated with other franchisors are in their zip code, suggesting a competitive effect. This result does not hold for unaffiliated units, possibly because they are more differentiated. This result implies that the pizza restaurant industry is one where benefits from agglomeration economies do not outweigh competition.

\subsection{Robustness Tests}

We conducted a variety of robustness tests in addition to the regressions estimated in Table 2. As mentioned above, we estimated Gompertz and Weibull models with no changes in significance levels for the variables of theoretical interest.

We estimated experience using discount factors other than the square root formulation used in Table 2. A linear discount factor provided almost identical results (only Hypothesis 3 was no longer supported), while the extremes of a quadratic discount factor and no discount factor provided almost no significant results for experience. This pattern is identical to that found in previous work (Ingram and
Baum 1997, Baum and Ingram 1998), strongly suggesting that experience depreciates approximately at the gradual rate of the square root of time.

We also estimated regressions using different definitions of "local." The results in Table 3 considered the 25 closest units and their associated experience as local. We also estimated regressions considering the closest 50 and 100 as local. The owner's local experience becomes insignificant for units unaffiliated with franchisors for the 50-unit definition. For all types of affiliation, the owner's local experience becomes insignificant using a 100-unit definition. The experience of other owners affiliated with the same franchisor remains significant and important at 50 and 100 units. These tests illustrate the truly localized nature of congenital experience.

We mentioned above that another approach to determining "local" status is to determine whether units are within the same administrative region, such as a county or zip code. We estimated regressions using these approaches, but found weaker significant effects for county and no significance for zip code. Counties likely yielded weaker systematic effects because of their large variance in size. For example, Harris County (home of Houston) was home to 428 pizzerias in 1999. Deaf Smith County only had two. Zip code counts were useful as a control to estimate a unit's level of direct competition, but many units in separate zip codes are close enough that we feel they should be considered local (and more than 50\% of zip codes had three or fewer pizza restaurants in 1999). Thus, the lack of effects using zip codes is not surprising.

Finally, we considered a form of similarity other than geographic proximity. We considered whether urban units would benefit more from experience at other urban units than at rural units, and symmetrically, whether rural units would benefit the most from other rural units. While evidence exists that similarity in the urban/rural dimension plays a role in the assignment of franchisees to units (Kalnins and Lafontaine 2004), we found no results that similar experience in this dimension was any more beneficial than dissimilar experience.

\subsection{Supplementary Analysis: Separation of Franchised and Company-Owned Units}

Though included only as a control variable in Table 2, we investigated in more detail the possible variance in effects between units affiliated with a franchisor via a contractual franchising relationship and those owned by the franchisors themselves. Many units were owned by the large franchisors in the 1990s. Pizza Hut owned 254 units (45\% of their total), while Domino's owned 72 units (23\% of their total) in 1999. Separate results for franchisee-owned and companyowned units are presented in Table 3. 


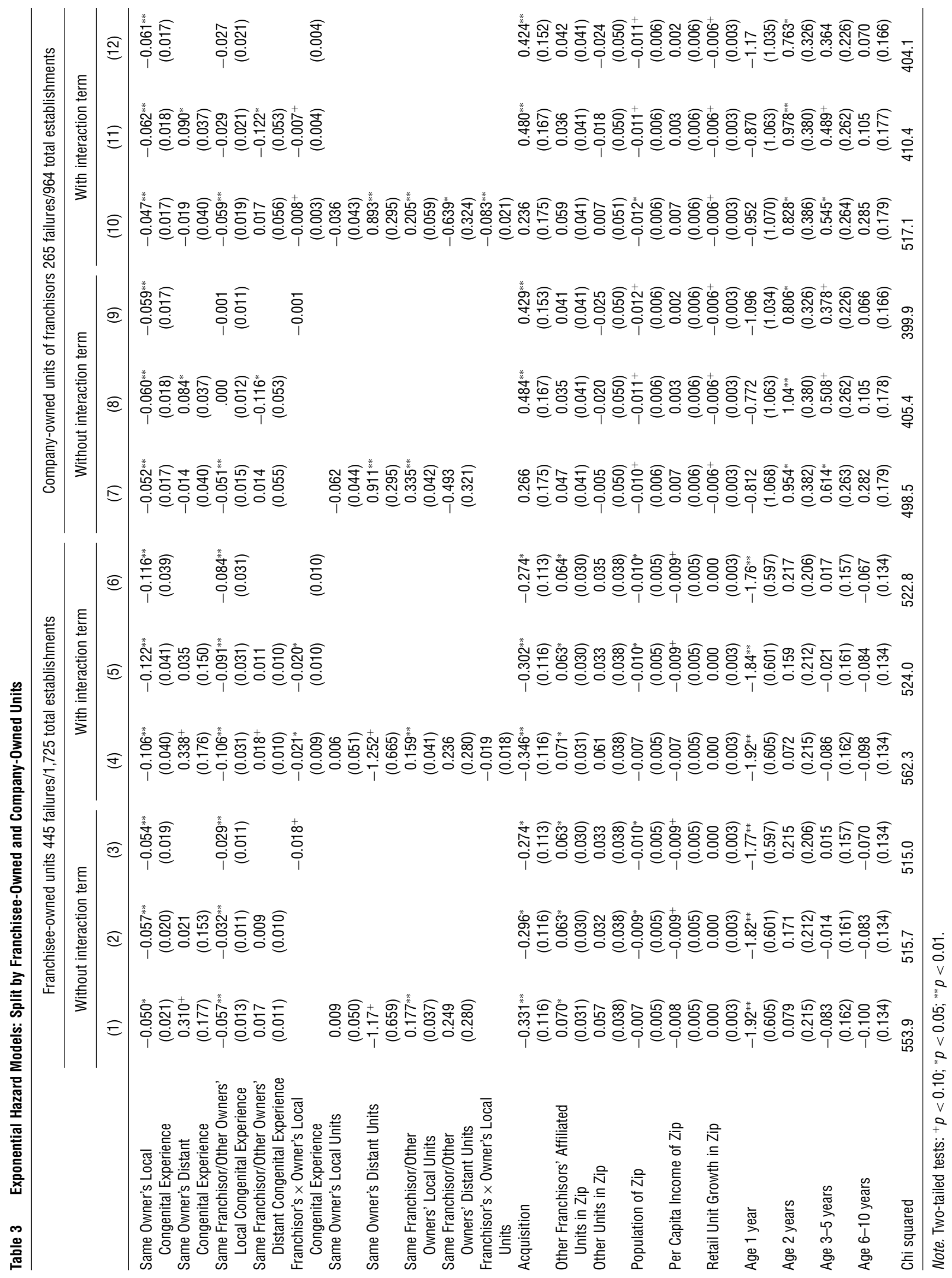


Before discussing the effects of congenital experience, we note more generally the strikingly similar failure rates of franchised and company-owned units. Between 1990 and 1999, there were 2,369 units total affiliated with franchisors. We note that 320 of these were at some point franchised and at some point company-owned units. Some periods from these 320 units appear in the franchised subsample analysis and others appear in the company-owned unit subsample analysis, depending on the unit's status in each period. Using these criteria, 445 failures took place during spells of franchisee ownership among the 1,725 units (25.8\%) that were at least at some point franchisee owned. Of 964 units $(27.4 \%)$ that were at some point company owned, 265 failed. These statistics are of interest because academics have hypothesized that company-owned units should be less likely to fail because companies take the best locations (Martin 1988) or more likely to fail because of agency problems (Knott and McKelvey 1999).

We also note the similarity in coefficient sizes for the Same Owner's Local Congenital Experience variable for the franchisee- and company-owned units. Further, we note that neither group has significant positive or negative effects from distantly gained congenital experience. At first, the localized nature of the benefits of experience of company-owned unit operation appears surprising. After all, franchisors successfully own units throughout their entire domain of operations. However, their individual district managers in charge of the company-owned units typically have a span of control of six to eight units (Bradach 1998, p. 46), implying that any tacit knowledge gained by these individuals is likely to transfer primarily to all units they oversee. Kalnins and Lafontaine (2004) found that, despite the presence of company-owned units throughout the chain's domain, the franchisors largely choose to own new units in clusters, just like their franchisees do, suggesting that the franchisor is taking advantage of the localized knowledge of one or more district managers in the region of the cluster.

Our second main observation from Table 3 is that the Same Franchisor/Other Owners' Local Congenital Experience variable for the company-owned units is insignificant, indicating that those units do not benefit from the local experience of nearby franchisees. Three institutional facts may explain this. First, while district managers have the same opportunities as franchisees to accumulate tacit knowledge that would be valuable for their units' survival, they may have fewer incentives to take action based on this knowledge (Knott and McKelvey 1999). Company managers are typically salaried, and it is rarely possible to structure a contract to give them the high-powered incentives that arise from unit ownership (Lutz 1995). Second, because they are embedded in a hierarchy, company managers are more likely than franchisees to make decisions based on what their superiors want to hear (Bradach 1998, pp. 44, 146). Third, the hierarchy often constrains the managers' ability to make decisions based on local knowledge, even if it may result in superior performance for their units (Lafontaine and Bhattacharyya 1995). Our finding complements other work that is consistent with these arguments. Yin and Zajac (2004) found that company-owned pizza restaurants were less successful than franchisees at managing complex strategies, such as the simultaneous operation of dine-in and delivery service.

\subsection{Caveats}

When using failure rates as a dependent variable, the benefits of a firm's experience are not always easy to distinguish from those of reputation and brand recognition. Much like experience, reputation builds up over time and may be localized. Using a cost-based dependent variable is one strategy to isolate the experience effect (e.g., Darr et al. 1995), but no such data are available for our population. Alternatively, testing the effects of the presence of a common business name across multiple units within a chain can distinguish these effects (e.g., Ingram and Baum 1997). In our case, all of the franchisors use the same name at all affiliated units, making such a distinction impossible for that group. Further, more than $80 \%$ of the franchisor-unaffiliated multiunit owners in our sample do business under the same name at all their units.

However, we are confident that at least a substantial proportion of our results capture knowledge-based benefits of congenital experience. While we acknowledge that "congenital reputation" is likely to be beneficial at the time of a unit's founding, it should not be as discontinuously important as congenital experience. First, as noted earlier, congenital experience can provide crucial insight for irreversible decisions such as site selection that will greatly affect the likelihood of a unit's failure. A poor reputation is unlikely to be as irreversible as a poor location decision. Second, we note that our franchised subpopulation largely consists of well-established chains such as Pizza Hut and Domino's, whose brand names and reputations were firmly implanted in the nation's consciousness well before the 1990s, our period of observation. Third, reputation or brand recognition would be unlikely to generate the complementary effect between the owner's and franchisor's local congenital experiences.

\section{Discussion}

This paper has presented robust evidence that the locally accumulated congenital experience of owners inhibits failure of their units. This result holds for 
units both unaffiliated and affiliated with franchisors, including the case where the franchisors themselves own the units. Our results are consistent with the notion that congenital experience is crucial because it informs the many irreversible decisions made at a unit's startup, in particular, the actual location decision for the unit.

The coefficients for owners' local congenital experience are similar in magnitude for units affiliated with franchised chains and those unaffiliated, indicating that an owner's experience in the local area is just as important within franchised chains as outside them. This finding may seem surprising from the point of view of some of the practitioner literature, because the franchisors often claim that their experience serves as a substitute for owners' own experience (see, e.g., Luxenberg 1985, pp. 19, 36). Yet when we consider past findings that crucial knowledge possessed by franchisee owners and their employees is tacit in nature (Argote and Darr 2001), our results not only make sense but also strengthen the notion that tacit knowledge is vital for success, even within the franchised chains that rely so much on codification.

Further supporting the idea of the importance of tacit knowledge within franchise systems is our finding that franchisees benefit from the local, but not distant, congenital experience of the other owners affiliated with the same franchisor. We had hypothesized that, because knowledge from other franchisees typically disseminates to a unit via the franchisor (Argote 1999, p. 91) and that because the franchisors strive to codify knowledge (e.g., Love 1986, p. 140), the experience accumulated throughout the franchisor's chain would be beneficial to a unit whether it was accumulated locally or distantly. Our results are inconsistent with this hypothesis, even showing occasional failure-increasing effects of distantly gained experience.

The localized nature of our findings suggests that the real value of the local congenital experience accumulated at the same franchisor's other units may come indirectly from the other franchisees, possibly via the franchisors' district managers. While franchisees may not directly help a different franchisee's fledgling unit for fear of encroachment and future competition, the franchisor's district managers may receive this knowledge, add some of their own local and tacit experience, and transmit this knowledge to an owner of a future unit. This knowledge may allow the owner to make informed decisions regarding site selection and other startup activities.

We also found that the local congenital experience of franchisees and that of other owners affiliated with the same franchisor act as complements: A franchisee's local congenital experience reduces unit failure more when the chain's other owners also have local congenital experience. This complementarity is theoretically interesting, as it indicates that an owner's local experience provides absorptive capacity, the underlying knowledge needed to assimilate external knowledge. Similar to firms needing to conduct their own R\&D to understand inventions created elsewhere (Cohen and Levinthal 1990), one's own local experience may be required to understand and interpret knowledge created by similar others. Interestingly, from our supplementary analysis, the company-owned units of the franchisor gain from no such complementarity, suggesting that the franchisor does not incorporate the local experience of the franchisees into their decision making regarding their new units. This finding suggests that high-powered incentives, along with a nonhierarchical organization structure, need to be in place for the units of the chain to take advantage of tacit knowledge possessed within the organization.

\section{Conclusion}

In this paper, we have presented robust evidence that the retail and service units of multiunit owners, whether affiliated with franchisors or not, benefited from their owner's local congenital experience. Units did not benefit from distantly gained experience. Further, local experience of other owners affiliated with the same franchisor reduced failure rates of units, just like their own multiunit owners' experience. Contrary to our hypothesis, franchisors' distant experience did not prove beneficial. Finally, among units affiliated with franchisors, a complementary effect was found for owner and franchisor congenital experience.

While local knowledge has long been considered valuable at a country level (e.g., Caves 1971), organizational research has only recently begun to discover the benefits of local knowledge at a more microgeographic level (Baum and Ingram 1997, Greve 1999). The results here strengthen the case for the importance of local knowledge at the microlevel of cities and towns, not just at a national or regional level. Even in franchised industries-where codification and standardization are at the core of competitive advantage - and even in an era of inexpensive transportation and almost costless global communication, tacit knowledge localized in nature and difficult to transmit to distant sites still appears to play a primary role in business success.

\section{Acknowledgments}

The authors thank Paul Adler, Francine Lafontaine, Julia Liebeskind, Will Mitchell, and Anand Swaminathan for reading previous drafts and making helpful suggestions. They also thank seminar participants at the 2002 Strategy Research Forum, Chesapeake, MD, the 2002 Marketing Science Conference, Edmonton, Alberta, and the Fall 2003 
Policy Seminar Series at UCLA's Anderson School. Finally, they thank three anonymous reviewers and the Management Science associate editor for their extensive efforts to help them improve the paper. The usual caveat applies.

\section{References}

Adams, J., A. Jaffe. 1996. Bounding the effects of R\&D: An investigation using matched establishment-firm data. RAND J. Econom. 27 700-721.

Adler, P., R. Cole. 1993. Designed for learning: A tale of two auto plants. Sloan Management Rev. 34 85-94.

Aiken, L., S. West. 1991. Multiple Regression: Testing and Interpreting Interactions. Sage Publications, Newbury Park, CA.

Almeida, P., B. Kogut. 1997. The exploration of technological diversity and the geographic localization of innovation. Small Bus. Econom. 9 21-31.

Argote, L. 1999. Organizational Learning: Creating, Retaining, and Transferring Knowledge. Kluwer Academic Publishers, Boston, MA.

Argote, L., E. Darr. 2001. Repositories of knowledge in franchise organizations: Individual, structural, and technological. G. Dosi, R. Nelson, S. Winter, eds. The Nature and Dynamics of Organizational Capabilities. Oxford University Press, Oxford, U.K., 51-78.

Argote, L., S. Beckman, D. Epple. 1990. The persistence and transfer of learning in industrial settings. Management Sci. 36 140-145.

Bates, T. 1998. Survival patterns among newcomers to franchising. J. Bus. Venturing 13 113-130.

Baum, J. 1999. The rise of chain nursing homes in Ontario, 1971-1996. Soc. Forces 78 543-584.

Baum, J., P. Ingram. 1998. Survival-enhancing learning in the Manhattan hotel industry, 1898-1980. Management Sci. 44 996-1016.

Baum, J., S. Li, J. Usher. 2000. Making the next move: How experiential and vicarious learning shape the locations of chains' acquisitions. Admin. Sci. Quart. 45 766-801.

Blair, R., F. Lafontaine. 2002. Legislating exclusive territories: Franchising encroachment and legislative proposals. Mimeo, University of Michigan, Ann Arbor, MI.

Bradach, J. 1997. Using the plural form in the management of restaurant chains. Admin. Sci. Quart. 42 276-303.

Bradach, J. 1998. Franchise Organizations. Harvard Press, Cambridge, MA.

Brickley, J. 1999. Incentive conflicts and contracting: Evidence from franchising. J. Law Econom. 42 745-774.

Byrd, D. 2001. When peers become teachers: The impact of inter-firm relationships on learning and performance. Unpublished doctoral dissertation, University of Michigan, Ann Arbor, MI.

Caves, R. 1971. International corporations: The industrial economies of foreign investment. Economica 38 1-27.

Chandler, A. 1977. The Visible Hand: The Managerial Revolution in American Business. Harvard University Press, Cambridge, MA.

Cohen, W., D. Levinthal. 1990. Absorptive capacity: A new perspective on learning and innovation. Admin. Sci. Quart. 35 128-152.

Darr, E., T. Kurtzberg. 2000. An investigation of partner similarity dimensions on knowledge transfer. Organ. Behavior Human Decision Processes 82 28-44.

Darr, E., L. Argote, D. Epple. 1995. The acquisition, transfer, and depreciation of knowledge in service organizations: Productivity in franchises. Management Sci. 41 1750-1762.

Greve, H. 1999. Branch systems and nonlocal learning in populations. A. Miner, P. Anderson, eds. Advances in Strategic Management. JAI Press, Stanford, CT, 57-80.

Huber, G. 1991. Organizational learning: The contributing processes and the literatures. Organ. Sci. 2 88-115.
Ingram, P. 1996. The Rise of Hotel Chains in the United States, 1896-1980. Garland, New York.

Ingram, P., J. Baum. 1997. Chain affiliation and the failure of Manhattan hotels, 1898-1980. Admin. Sci. Quart. 41 68-102.

Ingram, P., T. Simons. 2002. The transfer of experience in groups of organizations: Implications for performance and competition. Management Sci. 48 1517-1533.

International Franchise Association. 1991-1999. Franchise Opportunities Guide (Annual Editions). IFA Press, Washington, D.C.

Jaffe, A., M. Trajtenberg. 1999. International knowledge flows: Evidence from patent citations. Econom. Innovation New Tech. 8 105-136.

Jaffe, A., M. Trajtenberg, R. Henderson. 1993. Geographic localization and knowledge spillovers as evidenced by patent citations. Quart. J. Econom. 108 577-598.

Jakle, J., K. Sculle. 1999. Fast Food: Roadside Restaurants in the Automobile Age. Johns Hopkins University Press, Baltimore, MD.

Kalnins, A. 2004. An empirical analysis of territorial encroachment within franchised and company-owned branded chains. Marketing Sci. Forthcoming.

Kalnins, A., F. Lafontaine. 2004. Multi-unit ownership in franchising: Evidence from the fast-food industry in Texas. RAND J. Econom. Forthcoming.

Kaufmann, P. 1989. Costs and benefits of standardized franchise formats. J. Brown, ed. 1989 Proc. Soc. Franchising, International Franchise Association, Washington, D.C.

Knott, A. 2001. The dynamic value of hierarchy. Management Sci. 47 $430-448$.

Knott, A. 2003. The organizational routines factor market paradox. Strategic Management J. 24 929-943.

Knott, A., B. McKelvey. 1999. Nirvana efficiency: A comparative test of residual claims and routines. J. Econom. Behavior Organ. 38 365-383.

Kogut, B., U. Zander. 1992. Knowledge of the firm, combinative capabilities, and the replication of technology. Organ. Sci. 3 384-397.

Lafontaine, F., S. Bhattacharyya. 1995. The role of risk in franchising. J. Corporate Finance 2 39-74.

Litz, R., C. Stewart. 1998. Franchising for sustainable advantage? Comparing the performance of independent retailers and trade-name franchisees. J. Bus. Venturing 13 131-150.

Love, J. 1986. McDonald's: Behind the Arches. Bantam, New York.

Lutz, N. 1995. Ownership rights and incentives in franchising. J. Corporate Finance 2 103-130.

Luxenberg, S. 1985. Roadside Empires: How the Chains Franchised America. Viking, New York.

Martin, R. 1988. Franchising and risk management. Amer. Econom. Rev. 78 954-968.

Maskell, P., A. Malmberg. 1999. Localised learning and industrial competitiveness. Cambridge J. Econom. 23 167-185.

Nonaka, I. 1994. A dynamic theory of organizational knowledge creation. Organ. Sci. 5 14-37.

Salvaneschi, L. 1996. Location, Location, Location: How to Select the Best Site for Your Business. Psi Successful Business Library, Oasis Press, Portland, OR.

Stata Corp. 2001. Stata 7 Reference Q-St. Stata Press, College Station, TX.

von Krogh, G., I. Nonaka, K. Ichijo. 2000. Enabling Knowledge Creation: How to Unlock the Mystery of Tacit Knowledge and Release the Power of Innovation. Oxford University Press, New York.

Yin, X., E. Zajac. 2004. The strategy/governance structure fit relationship: Theory and evidence in franchising arrangements. Strategic Management J. 25 365-383.

Zander, U., B. Kogut. 1995. Knowledge and speed of the transfer and imitation of organizational capabilities: An empirical test. Organ. Sci. 6 76-92. 